Nuntius Antiquus, Belo Horizonte, v. 13, n. 2, p. 75-96, 2017

\title{
Drama, aporia e ironia no Mênon de Platão
}

\section{Drama, Aporia and Irony in Plato's Menon}

\section{Richard Romeiro Oliveira}

Departamento de Filosofia e Métodos

Universidade Federal de São João Del Rei, São João Del Rei, Minas Gerais / Brasil richardromeiro@hotmail.com

Resumo: Como é sabido, o diálogo platônico Mênon se encerra com a afirmação de uma aporia: de fato, no desfecho dessa obra, Sócrates proclama abertamente para seu interlocutor, o jovem tessálio Mênon, que nenhum conhecimento seguro foi por eles alcançado acerca daquilo que foi investigado ao longo das discussões anteriores, a saber: a questão concernente à gênese da virtude. Tal fracasso ocorre, porém, segundo o filósofo, porque não se pesquisou previamente o que é a virtude em si mesma. Estamos, assim, aparentemente, diante de uma dupla negatividade: nada sabemos acerca de como a virtude se origina, porque ignoramos a sua natureza. Valendo-se de uma abordagem que leva a sério o caráter dramático e literário do diálogo platônico, o presente artigo pretende mostrar como essa aporia final que surge ao termo das discussões do Mênon pode ser compreendida como um enunciado irônico, que envolve, nas suas entrelinhas, uma significação filosófica diferenciada em relação àquilo que é explicitamente declarado pela letra do texto.

Palavras-chave: virtude; aporia; drama; saber; ironia.

Abstract: As is well known, the Platonic dialogue Meno concludes with the assertion of an aporia. In fact, in the end of this work, Socrates openly proclaims to his interlocutor, the young Thessalian Meno, that no secure knowledge has been obtained by them about what was investigated during the previous discussions, namely: the question concerning the genesis of virtue. Such failure, however, occurs, according to the philosopher, because one has not previously researched what virtue is in itself. We are thus apparently faced with a double negativity: we know nothing about how virtue originates, because we ignore its nature. Making use of an approach that takes seriously the dramatic and literary character of the Platonic dialogue, the present article intends to show how this 
final aporia that emerges at the end of the discussions of the Meno can be understood as an ironic statement that involves, between the lines, a philosophical meaning that is different with regard to what is explicitly stated by the letter of the text.

Keywords: virtue; aporia; drama; knowledge; irony.

A proposta fundamental do presente texto consiste em tentar compreender, de uma forma mais adequada, o significado filosófico contido na conclusão do Mênon, procurando observar como o desfecho aparentemente negativo ou aporético desse diálogo deve ser lido e interpretado não apenas com base nas formulações dialéticas e argumentativas nele contidas mas também à luz dos elementos dramáticos presentes no texto. Como se sabe, o Mênon chega ao seu termo manifestando o fracasso das discussões ali travadas entre Sócrates e a personagem homônima acerca do problema da areté e de sua gênese: após uma série de argumentações sinuosas, de fato, os dois interlocutores desembocam finalmente na conclusão de que a virtude não é algo que existe por natureza (phýsei) nem coisa que se ensina (didaktón), mas, sim, um fenômeno misterioso, que advém (paragígnetai) aos homens graças a um favor divino (theia[i] moíra[i]), sem o concurso do intelecto (áneu nô̂). ${ }^{1}$ No entanto, tal conclusão, admite imediatamente Sócrates, não é inteiramente satisfatória, pois, observa o filósofo, só saberemos algo com segurança acerca da gênese da virtude quando "primeiro empreendermos pesquisar o que é afinal a virtude em si e por si mesma" (próteron epikheirésomen autò kath 'hautò dzeteîn tí pot'estin aretée ${ }^{2}-$ coisa que não foi feita adequadamente nos debates anteriores. Estamos, pois, de certa forma, diante de uma dupla negatividade: desconhecemos a natureza da virtude e, desconhecendo a natureza da virtude, não podemos saber como ela realmente se origina ou vem a ser. O ponto essencial que procurarei estabelecer por meio de minhas análises é que, se levamos em

\footnotetext{
${ }^{1}$ Mênon, 99 e. As citações do texto grego do diálogo são feitas, neste artigo, de acordo com a edição estabelecida por Bluck (2010). A tradução da obra de que nos utilizamos é a de Iglésias (2001).

${ }^{2}$ Mênon, 100 b.
} 
conta os elementos dramáticos presentes no Mênon, esses enunciados finais, de caráter aparentemente aporético, com os quais Sócrates encerra o diálogo, devem ser tomados não de forma literal, mas, antes, cum grano salis e, portanto, como propõe Gooch (1987, p. 189-204), como formulações irônicas, que, insinuando nas suas entrelinhas uma significação diferenciada em relação àquilo que é explicitamente afirmado pela letra do texto acerca da questão da virtude e da possibilidade de seu ensinamento, apontam para a filosofia como princípio que seria responsável pela determinação do que é a verdadeira areté.

Dados os limites de que disponho, não pretendo efetuar aqui uma abordagem pormenorizada do diálogo como um todo. Para os propósitos da minha exposição, dedicarei maior atenção sobretudo à seção final do texto, que se inicia a partir de $86 \mathrm{c}$ e que correspondente à última etapa das discussões entre Sócrates e Mênon, no intuito de observar os principais elementos dialógicos que ali se manifestam e como eles devem ser considerados na construção do significado derradeiro da obra. Do ponto de vista metodológico, o procedimento que buscarei aplicar no desenvolvimento de minha leitura consiste, basicamente, em valorizar a dimensão propriamente literária do texto platônico, explorando, nele, não apenas aquilo que diz respeito aos argumentos formulados e aos eventuais ensinamentos ou dógmata produzidos mas também tudo o que concerne à sua natureza dramática, ressaltando, assim, alguns pontos mais decisivos da ação que se consuma diante de nós por meio do debate entre Sócrates e Mênon. ${ }^{3}$ Semelhante abordagem assume como princípio hermenêutico essencial, como é fácil ver, a ideia de que o diálogo platônico é não a exposição sistemática e puramente abstrata de um saber já pronto e devidamente formalizado, mas um trabalho de certa forma teatral, que,

\footnotetext{
${ }^{3}$ Temos aqui, segundo creio, a adoção de uma estratégia interpretativa mais adequada na efetivação da abordagem da obra de Platão, algo que veio a ser mesmo reconhecido, por importantes comentadores modernos, como uma démarche hermenêutica e metodológica imprescindível para se alcançar uma compreensão mais consistente do significado do diálogo platônico. Cf. Friedländer (1973, p. 157; 167), Klein (1992, p. 3-9), Koyré (1995, p. 17-19) e Strauss (2005, p. 152-153)
} 
apresentando-nos uma mimese do ato mesmo de filosofar, pressupõe, por isso, no processo de constituição de seu significado filosófico mais fundamental, a colaboração silenciosa e reflexiva do leitor (ou do público) com o drama dialético que diante dele se desdobra. ${ }^{4}$

Ora, a correta aplicação desse expediente metodológico requer, a meu ver, antes de tudo, que se admita um dado de capital importância, a saber: o fato de que a dramatização levada a efeito nos textos de Platão envolve, via de regra, o recurso à ironia, o que acaba por conferir a eles, muitas vezes, um caráter malicioso, que, escamoteando de forma habilidosa o pensamento, envolve um jogo sutil de desvelamento e ocultação. Eis aí, sem dúvida, mais um ponto decisivo no trabalho de interpretação da obra platônica, pois, como já afirmara Friedländer (1973, p. 137), "não se pode abordar Platão sem levar em conta o que é a ironia e o que ela significa em sua obra". Não é, porém, meu objetivo, evidentemente, desenvolver aqui uma teorização cerrada do conceito de ironia, assunto controverso e complexo, sobre o qual muito já se escreveu, pois isso constituiria uma démarche completamente despropositada no contexto restrito deste artigo. Limitar-me-ei, pelo contrário, apoiandome naquilo que dizem alguns comentadores, ${ }^{5}$ a considerar a ironia platônica como um procedimento discursivo fundado em uma sofisticada forma de dissimulação e em um uso deliberado da ambiguidade, o que envolve a veiculação de uma mensagem cifrada, contendo uma tensão ou incongruência entre o pensamento e sua expressão. Ora, pode-se dizer que os diálogos de Platão se assentam em um uso consciente de tal procedimento, manejando com maestria o tipo de ardil retórico que lhe é próprio. Porém, para sermos mais precisos, devemos dizer que a ironia que aparece nos diálogos de Platão é não uma ironia simples, mas, antes, uma ironia de caráter duplo ou complexo. Para se compreender adequadamente esse ponto, é preciso perceber que há, no texto platônico, ao lado de uma ironia que poderíamos qualificar, seguindo Gooch (1987, p. 193), de "interna ao diálogo" (ou peça), e que se efetua no

\footnotetext{
${ }^{4}$ Sobre isso, cf. as valiosas observações de Klein (1992, p. 6-7)

${ }^{5}$ Ver Friedländer (1973, p. 144) e Strauss (2005, p. 151-152).
} 
jogo dialético, sinuoso e repleto de ambiguidades efetivado por Sócrates com seus interlocutores, uma outra forma de ironia, que se constitui não internamente, a partir da discussão entre Sócrates e seus interlocutores, mas externamente, por meio da relação estabelecida pelo público ou pelo eventual leitor do diálogo com aquilo que se passa na ação desenvolvida. ${ }^{6}$ Nesse segundo caso, estamos diante do que se poderia chamar de uma ironia dramática, a qual, para ser compreendida, requer a intervenção do público ou do leitor, que deve ser capaz de apreender a incongruência entre aquilo que é explicitamente dito pelas personagens e o sentido da ação ou do drama que elas efetivamente levam a efeito na cena. ${ }^{7}$

Pois bem, acreditamos que o Mênon constitui uma manifestação inequivocamente exemplar desse artifício literário e discursivo, de vez que seu desenvolvimento se apresenta penetrado por uma fina ironia, a qual se mostra presente tanto interna, i. e., em algumas formulações dialéticas propostas por Sócrates ao longo do debate, quanto externamente, i. e., no sentido da ação dramática que é posta em cena e que deve ser captada pelo leitor. No que diz respeito a essa última forma de ironia, acreditamos que a sua apreensão deve nos levar a uma atitude de suspeita em relação às asserções socráticas com que o diálogo se encerra, relativizando a confissão de fracasso ou de aporia que nelas explicitamente se manifesta. De modo mais preciso, acreditamos que o significado da ação ou do drama que se consuma no Mênon entre Sócrates e Mênon aponta para algo diferente do que o próprio filósofo afirma ao fim do diálogo, sugerindo, nas suas entrelinhas, que a resposta que é procurada pelos participantes da discussão acerca do problema da aretéencontra-se, de certa forma, no tipo de conhecimento filosófico que Sócrates delineia aos poucos, diante de nossos olhos, ao longo da obra, por meio de suas palavras e atos.

Evidentemente, o entendimento adequado desses elementos literários, essenciais para a constituição da mensagem filosófica da obra, exige, antes de tudo, como uma tarefa hermenêutica preliminar, a compreensão de quem é o principal interlocutor de Sócrates neste diálogo:

\footnotetext{
${ }^{6}$ Cf. Gordon (1999, p. 116).

${ }^{7}$ É o que esclarece Griswold, Jr.(2002, p. 87). Ver também Gooch (1987, p. 194).
} 
Mênon. Ora, quem é Mênon? Trata-se, decerto, de uma figura histórica, e não de uma personagem puramente fictícia. De fato, segundo as principais fontes antigas (Xenofonte e Diógenes Laércio) ${ }^{8}$ e modernas, ${ }^{9}$ Mênon era um jovem e rico aristocrata de Farsalo, próspera cidade da Tessália, que se tornou bastante conhecido no século IV a.C. ao tomar parte, como uma espécie de condottiere à frente de um exército de mercenários, na expedição militar organizada por Ciro contra Artaxerxes, seu irmão, para retomar o trono da Pérsia. Ao que tudo indica, esse mesmo Mênon participou da comissão enviada pelos tessálios a Atenas em 402 a. C., para solicitar o apoio desta cidade contra a política expansionista do tirano Licofrón de Feres, em virtude das conexões de sua família com os atenienses. Tal visita a Atenas teria oferecido a Platão, segundo CantoSperber (1993, p. 19), a motivação primeva para a composição do diálogo que tem como título o nome do jovem tessálio (sobretudo por causa disso, os principais comentadores modernos da obra concordam em estabelecer a data de 402 a.C. como data dramática da discussão que nela é retratada). ${ }^{10}$ No que diz respeito ao testemunho de Xenofonte, nossa principal fonte acerca do assunto, ${ }^{11}$ é importante notar que o retrato que dele se extrai da personalidade de Mênon não é nada lisonjeiro: com efeito, como viu Bluck (2010, p. 124), Mênon é apresentado pelo general ateniense, na obra mencionada, como um sujeito desprovido de escrúpulos, como "um homem desleal, completamente imoral e egoísta - alguém cuja motivação fundamental é a ganância". ${ }^{12}$ Conforme a lapidar formulação de Jowett, ${ }^{13}$ Mênon seria, assim, uma espécie de "Alcibíades tessálio", e foi essa representação fundamentalmente negativa da personagem que se cristalizou no imaginário moral da época. ${ }^{14}$

\footnotetext{
${ }^{8}$ Cf. Xenofonte, Anabase, II, 6, 21-29; Diógenes Laércio, II, 50.

${ }^{9}$ Ver as informações fornecidas por Canto-Sperber (1993, p. 17-20) e Bluck (2010, p. 120-124).

${ }^{10}$ Ver, por exemplo, Bluck (2010, p. 122).

${ }^{11}$ Cf. Klein (1992, p. 36).

${ }^{12}$ Cf. também Klein (1992, p. 36-37).

${ }_{13}$ Apud Canto-Sperber (1993, p. 18).

${ }^{14} \mathrm{Cf}$. as observações de Klein (1992, p. 37).
} 
Platão, em seu diálogo, não é tão hostil na apresentação de Mênon quanto Xenofonte, mas nos mostra fortes traços de ambição política em seu éthos e em seu comportamento. É o que realmente transparece na obra, quando, nela, Mênon define a excelência, em um primeiro momento, como a "capacidade de comandar os homens", e, em seguida, após ser refutado por Sócrates, como "o desejo das coisas boas e a capacidade de adquiri-las"; 15 quando, tornando evidente sua tábua de valores, ele apresenta, como bens, a posse de riquezas, o poder e a honra: ${ }^{16}$ ou quando, enfim, ele omite a piedade em sua lista de virtudes, colocando em seu lugar a magnificência (megaloprépeia). ${ }^{17}$ Ademais, Mênon é mostrado no texto platônico como um indivíduo vaidoso e orgulhoso de sua beleza ${ }^{18}$, e como alguém que tem muitos amantes (erastai) ${ }^{19}$ e muitos servidores (akólouthoi).$^{20}$ Discípulo de Górgias, ele é igualmente apresentado como um retórico habilidoso, que já fez muitos discursos sobre a virtude, mas que é, porém, incapaz de defini-la filosoficamente. ${ }^{21}$ Enfim, deve-se notar que, no diálogo, Mênon aparece, em certos momentos, como alguém dotado de uma boa paideía e possuidor de alguns dotes intelectuais, mas que, por sua impetuosidade, seu espírito afoito e sua preguiça, não possui verdadeira disposição filosófica, carecendo de "paciência dialética", o que o faz ansiar sempre por respostas prontas e imediatas. ${ }^{22}$

Seguindo Bluck (2010, p. 125-126), poderíamos pensar que é provável que Platão, em seu diálogo, estivesse interessado, porém, não tanto em fornecer um retrato fiel de Mênon, mas em elaborar, baseandose nessa personagem histórica, uma espécie de tipo moral e psicológico apto a representar o éthos próprio do novo político aristocrático grego, intelectualmente emancipado dos tabus da moralidade convencional

\footnotetext{
${ }^{15}$ Mênon, $73 \mathrm{c} ; 77 \mathrm{~b}$.

${ }^{16}$ Mênon, $78 \mathrm{c}$.

${ }^{17}$ Mênon, 74a.

${ }^{18}$ Mênon, $80 \mathrm{c}$.

${ }^{19}$ Mênon, 70 b; 76 b-c.

${ }^{20}$ Mênon, 82 a.

${ }^{21}$ Mênon, $80 \mathrm{~b}$.

${ }^{22}$ Ver Canto-Sperber (1993, p. 24).
} 
e ávido de honras, glórias e poder. Dito de outra maneira, como viu Canto-Sperber (1993, p. 24), o Mênon platônico é uma representação do pragmatismo político da época, oriundo de um certo ensinamento sofístico e assentado em uma concepção da virtude como mero instrumento para a consecução de honras e sucesso social. Ora, atentando para tudo isso, percebemos desde já um elemento irônico fundamental, de caráter propriamente dramático, subjacente à construção da obra platônica. Com efeito, Platão coloca como principal interlocutor de Sócrates em um diálogo que versará sobre o problema da virtude ou excelência humana um homem que possui os bens mundanos mais estimados (beleza, riqueza, poder, eloquência etc.), menos aquilo que Sócrates consideraria como a verdadeira excelência ou virtude. Há, assim, uma discrepância profunda entre aquilo que a figura de Mênon faz e representa na obra e aquilo que, ao longo do desenvolvimento do diálogo, se pretende discutir e compreender, vale dizer, a questão da areté, uma discrepância que o leitor mais atento deve ser capaz de apreender e identificar.

Ora, em contraste com elementos apontados acima relativos a Mênon, Sócrates aparece, na obra, como a antítese mesma do nobre tessálio: de fato, ele é pobre, velho, feio, desprovido de sangue nobre e, para alguns padrões convencionais, não muito educado, ${ }^{23}$ não obstante, ele encarna, no diálogo, a figura do verdadeiro filósofo, i. e., a figura daquele que manifesta uma incansável disposição para o pensamento e a pesquisa, e que, apesar de afirmar não saber o que é a excelência humana, paulatinamente nos é mostrado no interior do diálogo, por um sutil deslocamento dramático, como o único homem que, naquele cenário, a possui. Temos aí, sem dúvida, outro efeito irônico importante do texto, produzido por Platão com grande habilidade literária, considerando a confrontação dramática entre Sócrates e Mênon, efeito este que constitui um elemento dotado de inquestionável importância para a constituição do significado filosófico da obra.

Vale a pena registrar aqui, ainda, no que concerne ao tratamento das dialogi personae, a presença de uma outra figura importante no

${ }^{23}$ Cf. Bluck (2010, p. 124-125). 
contexto dos debates do Mênon. Trata-se de Ânito, elemento notório do partido democrático em Atenas e que foi um dos principais acusadores responsáveis pelo processo que culminou com a condenação de Sócrates em 399 a.C. Esse episódio é antecipado dramaticamente nas páginas do diálogo, mais especificamente na passagem em que Ânito ameaça o filósofo por suas considerações nada favoráveis ou lisonjeiras acerca dos políticos atenienses. ${ }^{24} \mathrm{De}$ origem humilde, Ânito tornou-se rico graças a um negócio de curtição de couro e, por meio de sua riqueza, adquiriu certa influência política quando da restauração da democracia em Atenas, em 403 a.C. No diálogo, como nota Croiset (1965, p. 228), Ânito aparece como alguém ligado a Mênon "por relações hereditárias de hospitalidade" (a família de Ânito recebeu, em Atenas, familiares de Mênon em diversas ocasiões) e como um homem intelectualmente limitado, que manifesta total impaciência com as discussões desenvolvidas por Sócrates, endossando uma visão absolutamente convencional da virtude ou excelência. Com efeito, para Ânito, virtude ou excelência nada mais são do que aquilo que a sociedade reconhece como tal, e isso, preconiza ele, qualquer homem de bem de Atenas (kalòs kagathós) é capaz de ensinar. ${ }^{25}$ Percebe-se, assim, que Ânito encarna o mais tacanho conformismo pequeno-burguês, com sua misologia, sua aversão à filosofia e ao questionamento e sua adesão cega ao status quo e aos valores instituídos. ${ }^{26}$ Pode-se dizer, porém, seguindo, mais uma vez, Bluck (2010, p. 126), que, na economia dramática e discursiva do diálogo, essa personagem constitui uma espécie de contraparte democrática da figura aristocrática de Mênon, na medida em que ambos encarnam uma visão puramente socioinstrumental - e, portanto, não filosófica - da areté. ${ }^{27}$

\footnotetext{
${ }^{24}$ Mênon, 94 e.

${ }^{25}$ Mênon, 92 e.

${ }^{26}$ Ver Canto-Sperber (1993, p.29-32) e Koyré (p. 27, n. 1)

${ }^{27}$ Sobre a afinidade fundamental entre as figuras de Mênon e Ânito, no que diz respeito às suas concepções de areté, ver também Koyré (1995, p. 27, n. 2), que é citado por Bluck, e as seguintes formulações de Canto-Sperber (1993, p. 26): "Mais Ménon, l'aristocrate de Farsale, n'est pas le seul à reduire la vertu à l'exercice du pouvoir. Anytos, le democrate d'Athènes, nous en présente une autre face, encore plus opposée à la vertu socratique".
} 
Pois bem, tentemos ver rapidamente agora como esses personagens interagem na obra e a que conclusão eles chegam acerca do problema da excelência ou virtude que nela é discutido, buscando observar como o que está em jogo nessa conclusão pode ser interpretado como uma formulação irônica. O diálogo começa, como se sabe, ex abrupto, após a evocação de uma questão moral bastante discutida nos meios intelectuais da Atenas do século IV a.C.: Mênon quer saber de Sócrates se a virtude é algo que se ensina (didaktón) ou algo que se pode adquirir pelo exercício (asketón) ou, enfim, algo que sobrevém aos homens por natureza (phýsei paragígnetai tô̂s anthrópois). ${ }^{28}$ Aos questionamentos colocados por Mênon - os quais, como viu Klein (1992, p. 38 ), assumem um aspecto nitidamente cômico, se levamos em conta o caráter moralmente controverso da personagem -, Sócrates declara-se incapaz de dar qualquer resposta, afirmando que nem ele nem qualquer outro ateniense sabe se a virtude é algo que se ensina ou não. E a razão disso, a seu ver, é bastante clara: ele, Sócrates, não pode saber se a excelência se ensina ou não simplesmente porque não sabe absolutamente nada sobre ela (hos ouk eidós perì aretếs tò parápan) ${ }^{29}$ Ora, prossegue o filósofo, como alguém que não sabe o que uma coisa é (hó dè mè ô̂da tí estin) poderia saber como ela é (pôs án hopôón ge ti eideíen?), quer dizer, que atributos possui? Por exemplo: se alguém não conhece Mênon, como esse alguém poderia saber se Mênon é belo, rico, nobre ou o contrário de todas essas coisas? Temos aqui, como se vê, no começo do texto, uma típica ocorrência da confissão socrática de ignorância, a qual é tornada bastante enfática pelo uso do advérbio parápan. Veremos daqui a pouco que, quando Mênon formular seu célebre dilema epistemológico, ele se valerá justamente deste mesmo advérbio para, contra Sócrates, colocar em dúvida a possibilidade daquilo que Sócrates mais almeja, a saber: procurar algo que se ignora completamente. Seja como for, por meio das formulações acima apresentadas, observamos a primeira e mais fundamental lição metodológica fornecida pelo filósofo ao seu jovem

\footnotetext{
${ }^{28}$ Mênon, 70 a.

${ }^{29}$ Mênon, 71 a.
} 
interlocutor, lição que será infelizmente descurada por esse interlocutor em um momento posterior do debate: a de que a pergunta pela essência de algo deve preceder necessariamente a pergunta por suas qualidades, o que vem a tornar a investigação acerca da natureza da coisa o procedimento filosófico mais primordial.

Pois bem, na sequência do texto, o jovem político tessálio diz ter compreendido o que Sócrates lhe propõe, mas as duas respostas iniciais que avança, a saber, que a virtude é a capacidade de comandar os homens e que a virtude é o desejo das belas coisas, acompanhado do poder de adquiri-las, são facilmente desmontadas por Sócrates, mediante a aplicação de seu método elêntico tradicional. ${ }^{30}$ Não analisarei aqui os pormenores dessa argumentação socrática. Interessa-me apenas observar que essas tentativas de definição formuladas por Mênon possuem um valor fundamental na construção do significado dramático do diálogo, sendo, por isso, dignas de uma atenção especial da parte do leitor, porquanto são reveladoras do éthos ou da personalidade própria dessa personagem. Com efeito, definindo a excelência humana como a capacidade de governar os homens e como o poder de adquirir coisas belas, o jovem tessálio manifesta as inclinações visceralmente ambiciosas que habitam sua natureza e que o conduzem a ver a perfeição humana como algo inteiramente vinculado à aquisição do poder.

No desenvolvimento do diálogo, após ser refutado por duas vezes, Mênon cai em estado de aporia e perplexidade, confessando seu embaraço e sua incapacidade de dizer o que é a areté - justamente ele, Mênon, que discursou inúmeras vezes sobre tal assunto, com desenvoltura, diante de inúmeros homens. Nas palavras do nobre tessálio: "Sim, miríades de vezes (kaítoi myriákis), sobre a virtude (peri aretêss), pronunciei numerosos discursos (pampóllous lógous eíreka), para multidões (kai pròs polloús), e muito bem (kaì pánu ê̂) como pelo menos me parecia. Mas agora nem sequer o que ela é, absolutamente, sei dizer (nyn dè oud'hóti estìn tò parápan ékho eipeîn)." Manifestando certa irritação com o procedimento socrático e com aquilo que dele resulta - a redução

\footnotetext{
${ }^{30}$ Mênon, $73 \mathrm{c}-79$ e.
} 
ao estado de aporia -, Mênon então observa a Sócrates que ele faz muito bem em permanecer em Atenas e em não viajar ao exterior, pois, caso o filósofo se atrevesse, como estrangeiro, a adotar tais práticas fora de sua cidade natal, "rapidamente seria levado ao tribunal como feiticeiro". 31 A essa altura do debate e observando os enunciados e o comportamento de Mênon, o leitor atento já terá provavelmente percebido que uma discussão de Sócrates com um interlocutor dessa natureza não poderá evidentemente chegar a bom termo. Seja como for, apesar do embaraço e da irritação de Mênon, Sócrates o incita a levar adiante a pesquisa e a retomar, com ele, a procura pela natureza da virtude. Aproveitando-se da situação aporética e com o intuito de encurralar o filósofo e bloquear o desdobramento da investigação dialética, o jovem tessálio lança, porém, diante de Sócrates, um insidioso dilema, destinado a evidenciar a impossibilidade daquilo que o filósofo se propõe a fazer: procurar algo que se ignora completamente. ${ }^{32}$

Mais uma vez, não poderei discutir aqui, de forma mais aprofundada, essa passagem crucial do diálogo. Gostaria apenas de observar duas coisas em relação a ela: 1) em primeiro lugar, que o dilema de Mênon é, de certa forma, como viu Canto-Sperber (1993, p. 247, n. 104), uma resposta sarcástica da personagem à lição metodológica enunciada por Sócrates no início do diálogo (lição que determinava que não se pode falar acerca das qualidades de uma coisa cuja natureza ignoramos por completo), na medida em que funciona como uma réplica do seguinte tipo: "de que forma alguém poderia se colocar à procura de algo que desconhece absolutamente, como quer Sócrates?" (evidentemente, a força da objeção de Mênon repousa sobre o uso do advérbio parápan, "absolutamente", "completamente", o qual é utilizado pelo próprio Sócrates, como vimos acima, quando confessa, no começo da discussão, ignorar por completo o que é a virtude; Mênon pretende, assim, voltar a confissão socrática de ignorância contra o próprio Sócrates); 2) em segundo lugar, que, apesar de qualificar o dilema de Mênon de

\footnotetext{
${ }^{31}$ Mênon, 80 b.

${ }^{32}$ Mênon, $80 \mathrm{~d}$.
} 
argumento erístico (lógon eristikón), i. e., de argumento forjado com o claro propósito de funcionar como uma armadilha verbal, Sócrates parece levar bastante a sério o paradoxo epistemológico que nele se formula, tratando-o como algo filosoficamente relevante. ${ }^{33}$ Ora, é justamente para escapar desse paradoxo e justificar a possibilidade da pesquisa e, por conseguinte, da filosofia - que o filósofo, no diálogo, elaborará sua concepção do conhecimento como uma forma de anámnesis, i. e., como um trabalho de rememoração de um saber já presente em nós, mas que se encontra em estado de latência. Por meio dessa concepção, Sócrates pretende mostrar, contra o dilema de Mênon, a existência de uma situação epistemológica intermediária entre a ignorância completa e o saber integral, situação que pode ser concebida justamente como uma espécie de conhecimento latente. Como se sabe, Sócrates não construirá uma argumentação para demonstrar essa visão, mas recorrerá, para tanto, a dois procedimentos diferenciados: o uso de um relato mítico e a realização de uma experiência maiêutica com um jovem escravo, envolvendo a resolução de um problema geométrico. No que diz respeito ao segundo procedimento, o que Sócrates pretende mostrar é que alguém que não possui qualquer instrução formal nas ciências matemáticas pode chegar a compreender onde se encontra a solução para um problema geométrico relativamente complexo, o da duplicação de um quadrado, desde que seja corretamente interrogado. Segundo a explicação socrática, o escravo - teoricamente "ignorante" da geometria - compreendeu qual seria a resposta para o problema proposto, não porque ele, Sócrates, assim o ensinou (isto é, ditou-lhe uma fórmula pronta relativa à questão), mas porque, graças ao questionamento correto, pôde ver por si mesmo onde tal resposta deveria ser buscada, o que mostra que as sementes do conhecimento geométrico já se encontravam em sua alma. ${ }^{34}$

Graças a essa formulação epistemológica, que desmonta o paradoxo de Mênon contra a possibilidade teórica da investigação e da procura do conhecimento, Sócrates julga, então, que eles podem retornar

\footnotetext{
${ }^{33}$ Ver Bluck (2010, p. 8).

${ }^{34}$ Mênon, 82 b-86 c.
} 
à pesquisa sobre o que é a virtude. Mênon, no entanto, está por demais ansioso e, afoitamente e sem qualquer reflexão, pede ao filósofo para que eles retornem não à questão sobre a natureza da virtude, mas à questão inicial do diálogo, i. e., à questão relativa à ensinabilidade da excelência. Sócrates reitera suas observações anteriores e lembra Mênon de que não se pode saber se a virtude se ensina ou não, se antes não se investigar o que ela é em si mesma. No entanto, ele cede aos apelos de seu interlocutor e aceita violar o princípio metodológico inicialmente estabelecido - não investigar a qualidade de um objeto do qual ignoramos ainda a essência -, enveredando novamente pela abordagem do problema se a excelência é ou não algo que se ensina, com a condição de que tal questão seja atacada mediante um outro procedimento metodológico, i. e., por meio de uma forma de argumentação diferenciada, que procede segundo a formulação de uma hipótese (ex hypothéseos). ${ }^{35}$ Sócrates observa que esse método é o procedimento empregado tipicamente pelos geômetras e que ele consiste, essencialmente, em se raciocinar de modo conjetural, com base no estabelecimento de um postulado. Ora, na perspectiva socrática, aplicado ao problema do ensinamento da areté, esse procedimento nos conduz à formulação de um postulado bastante simples: para que a virtude seja algo que se ensina, diz o filósofo, é preciso, antes de mais nada, que ela seja um saber (epistéme), pois o saber é a única coisa que realmente se ensina ao homem (oudèn állo didásketai ánthropos è epistémen). ${ }^{36}$ Formulada a hipótese, Sócrates passa, então, à dedução de suas consequências: se a virtude é um saber, e se ela é ensinada, ela não é algo que se possui por natureza e deve ter, por conseguinte, seus mestres e discípulos (levando em conta, por analogia, aquilo que se passa com as outras técnicas e artes). Mas, acrescenta com uma ponta de dúvida o filósofo, quem são os mestres ou os professores de virtude? Sócrates confessa que ele, pelo menos, jamais os encontrou em parte alguma. ${ }^{37}$ Nesse ponto da discussão, Ânito aparece abruptamente na cena do diálogo, e Sócrates o

\footnotetext{
${ }^{35}$ Mênon, 86 d-e.

${ }^{36}$ Mênon, 87 b-c.

${ }^{37}$ Mênon, 89 a-e.
} 
convida a participar do debate, explicando ao político ateniense que ele e Mênon investigam quem são os professores de virtude. A fim de tornar claros os termos do problema discutido, Sócrates desenvolve para Ânito o seguinte raciocínio: se quiséssemos que Mênon se tornasse um bom médico, o enviaríamos evidentemente para os médicos; se quiséssemos que se tornasse um bom sapateiro, o enviaríamos aos sapateiros; e o mesmo se passa com o aprendizado de todas as demais técnicas. Mas se quiséssemos torná-lo excelente e virtuoso, para quem o enviaríamos? Para os sofistas? Ânito se escandaliza com a sugestão de Sócrates e roga para que nenhum dos seus amigos ou concidadãos se aproxime desses homens nefastos e nefandos, porquanto "eles são uma manifesta ignomínia e uma ruína para os que os frequentam". ${ }^{38}$ Aos seus olhos, os sofistas não passam de mercenários cujos ensinamentos não têm qualquer valor. Loucas são, assim, as cidades que acolhem esses indivíduos em suas fronteiras, ao contrário de expulsá-los, afirma ele. ${ }^{39}$ Sócrates pergunta, então, a Ânito se os sofistas lhe fizeram algum mal, já que ele se mostra tão agressivo com relação a eles. Ânito responde que não, porquanto jamais se aproximou de um deles. Sócrates mais uma vez encontra, nessa resposta, ensejo ou oportunidade para ironizar: como, pergunta ele, Ânito pode saber algo sobre os sofistas, se é desprovido de qualquer experiência com eles? Para saber algo dos sofistas, sendo totalmente desprovido de experiência com esses homens (ápeiros pantápasi tôn andrônn), Ânito deve ser, quiçá, um adivinho (Mántis ê̂̀ ísôs, $\underline{\hat{o}}$ Ányte). ${ }^{40}$ De qualquer forma, indaga o filósofo, se os sofistas não são mestres de virtude, a quem Ânito considera que devemos nos dirigir para nos tornarmos excelentes? A resposta de Ânito à indagação socrática é bastante reveladora de seu caráter conformista e pouco reflexivo: para tornar alguém excelente, basta que o entreguemos a qualquer ateniense que seja um homem de bem (kalòs kagathós). ${ }^{41}$ Sócrates concorda com Ânito que há e houve em Atenas homens bons, mas duvida de que esses homens tenham sido

\footnotetext{
${ }^{38}$ Mênon, 89 e-91c.

${ }^{39}$ Mênon, 92 a-b.

${ }^{40}$ Mênon, 92 c.

${ }^{41}$ Mênon, 92 e.
} 
capazes de ensinar a excelência aos seus próximos. Pelo menos é o que parece, a seu ver, ensinar a história: nenhum dos grandes políticos atenienses (Temístocles, Tucídides, Aristides ou Péricles) soube tornar outrem - nem mesmo sua própria prole - verdadeiramente virtuoso, o que parece mostrar que a virtude não é algo que se ensina (ou didaktón areté $).{ }^{42}$ Com essa formulação, Sócrates dá início ao procedimento de desqualificação dos políticos de Atenas que ocupará os momentos finais do diálogo, procedimento este que procurará mostrar que os políticos de Atenas não podem ser tidos como mestres de areté justamente porque eles não sabem o que ela, a areté, verdadeiramente é. Ora, ante as considerações socráticas, Ânito diz ao filósofo, já irritado, que ele, Sócrates, difama e conspurca Atenas e seus cidadãos, e o aconselha, em um tom de certa forma ameaçador, a ser mais precavido e a tomar um maior cuidado com suas palavras. ${ }^{43}$

Tocamos aqui, com essa fala de Ânito, mais um elemento de ironia dramática presente no desenvolvimento da ação posta em cena pelo diálogo. De fato, as palavras de Ânito contêm uma antecipação funesta e sombria do processo que será desencadeado posteriormente contra Sócrates em 399 a.C. e que culminará com a morte do filósofo no mesmo ano. Os participantes do diálogo nada sabem disso, evidentemente, uma vez que o debate no qual estão engajados ocorre em uma data anterior ao triste episódio que levará ao fim de Sócrates (a data dramática do Mênon é, como dissemos, 402 a. C.; o processo e a condenação de Sócrates, por sua vez, ocorreram em 399 a. C.). Mas o leitor ou espectador do Mênon, que lê ou vê o que se passa na cena do diálogo após aqueles trágicos acontecimentos, sabe de tudo e pode, pois, captar o significado dramático que Platão pretende transmitir com a construção dessa cena.

Seja como for, por meio dessa mise-en-scène, o diálogo torna perfeitamente claro que Ânito se irrita com Sócrates precisamente por não suportar o questionamento incessante efetuado pelo filósofo, que não poupa nada nem ninguém, o que vem a nos mostrar que para ele, Ânito, como para todo típico conformista, a virtude não é objeto de discussão,

\footnotetext{
${ }^{42}$ Mênon, 93 b- 94e.

${ }^{43}$ Mênon, 94 e.
} 
de debate ou de indagação, mas algo dado e que se deve receber dos antepassados e se aceitar passivamente, sem qualquer crítica ou reflexão.

Visto que Ânito se mostra inapto à discussão, fechando-se ao diálogo, Sócrates retorna, então, a Mênon e, interrogando-o mais uma vez, aponta para o fato de que se a virtude não pode ser ensinada, ela não é, portanto, um saber. Mênon não tem qualquer objeção a fazer a isso. Na verdade, diz ele, tal é justamente o ensinamento de seu mestre Górgias, o qual sempre escarneceu daqueles que pretendem ensinar a areté..$^{44}$ Mas, retoma Sócrates, com essa argumentação não esgotamos ainda todas as possibilidades de definir a virtude, pois é certo que, além do saber, um outro princípio é capaz de guiar a ação, qual seja: a opinião correta (orthé dóxa), que atua como uma crença cega, mas eficaz e certeira, capaz de, como tal, conduzir a práxis e levá-la a bom termo. Isso significa, diz o filósofo, que, do ponto de vista estritamente prático, a opinião correta pode fazer as vezes do conhecimento..$^{45}$ Mênon, no entanto, não acompanha o raciocínio socrático e diz não compreender a distinção por ele proposta entre dóxa e epistéme. Sócrates lhe explica, então, que as opiniões se distinguem do saber pelo fato de serem instáveis e fugidias, como as estátuas do legendário escultor Dédalo, que, sempre móveis, não permanecem nunca no mesmo lugar, e que tais opiniões só se tornam estáveis, sólidas, quando encadeadas com o raciocínio da causa (aitías logismós), mecanismo que as transforma precisamente em saber. ${ }^{46}$ Contudo, reitera ainda uma vez o filósofo, no terreno da ação, a opinião correta pode funcionar muito bem como um sucedâneo precário do saber. Ora, nota Sócrates, foi graças a essa opinião correta que os políticos atenienses conseguiram governar a cidade com êxito. Todavia, acrescenta ele logo depois, foi também por possuírem apenas essa opinião, e não o conhecimento, que tais homens não foram sábios (sophoí) e, carecendo de sabedoria (sophía), não puderam ensinar a excelência aos seus filhos e concidadãos. ${ }^{47}$

\footnotetext{
${ }^{44}$ Mênon, $95 \mathrm{c}$.

${ }^{45}$ Mênon, 96 d-97 c.

${ }^{46}$ Mênon, 97 c- 98 b.

${ }^{47}$ Mênon, 99 b.
} 
Ora, como um intérprete mais perspicaz é capaz de perceber, essas formulações epistemológicas elaboradas por Sócrates se encontram penetradas por uma sutil e perversa ironia, uma ironia que o afoito Mênon não é capaz, porém, de captar. Com efeito, Mênon não se dá conta de que para dizermos que uma opinião é correta é preciso sabermos qual é a opinião incorreta, e tal só é possível, obviamente, mediante a posse de algum tipo de conhecimento. Dito de outra maneira, não podemos dizer que uma opinião é verdadeira sem possuir o conhecimento da verdade, e possuir o conhecimento da verdade é ter epistéme. A concepção socrática de que a opinião correta pode funcionar, na prática, como um sucedâneo do saber envolve, pois, uma sutil zombaria com Mênon, zombaria que o jovem retórico, discípulo de Górgias, não pode, no entanto, perceber. ${ }^{48}$

Ora, após relegar a virtude dos grandes homens políticos de Atenas ao terreno da opinião, recusando a essa virtude qualquer sabedoria e orientação epistêmica, o filósofo a tratará, nos derradeiros momentos do diálogo, como um fenômeno pertencente ao campo da inspiração ou como um tipo de entusiasmo, mediante a comparação dos políticos à casta dos adivinhos, dos profetas e dos poetas: de fato, diz Sócrates, tanto uns quanto outros falam verdades sobre muitas coisas, mas sem saber absolutamente nada sobre aquilo de que falam. ${ }^{49}$ É justo, assim, dizer que tais homens são divinos (theíous), visto que, mesmo não tendo inteligência ou pensamento (noûn mè ékhontes), realizam com sucesso coisas muito importantes nas cidades. ${ }^{50} \mathrm{~A}$ consequência que Sócrates extrai finalmente dessa argumentação é, assim, a de que a excelência não é nem natural nem algo que se ensina (areté án eíe oúte phýsei oúte didaktón), mas algo que advém aos homens por um acaso divino (allà theía[i] moíra[i] paragignoméne), i. e., algo que sucede por meio da ocorrência de um acidente imprevisível, sem intervenção da inteligência ou do pensamento (áneu noû) - a menos, acrescenta o filósofo, que surja entre os políticos alguém capaz de realmente ensinar os outros a

\footnotetext{
${ }^{48}$ Cf. Koyré (1995, p. 31).

${ }^{49}$ Mênon, 99 b-c.

${ }^{50}$ Mênon, 99 c-e.
} 
ser político. ${ }^{51}$ Tal homem, conclui Sócrates, seria, no que diz respeito à virtude (pròs aretén), entre os seus companheiros, como um Tirésias no reino do Hades, ou como uma coisa verdadeira (alethès prágma) do lado de meras sombras (parà skiàs). ${ }^{52}$

Após um longo e sinuoso percurso dialético, o diálogo desemboca, assim, na ideia de que a virtude advém aos homens por uma concessão divina, vale dizer, por um acaso imponderável. Mas, de vez que a pesquisa, como vimos, foi conduzida somente por hipótese, não temos um conhecimento mais seguro sobre como a virtude ou excelência realmente se produz. Para tanto, esclarece Sócrates, seria preciso investigarmos antes o que é a areté em si mesma. Ora, justamente por não ter efetuado o procedimento dialético e metodológico correto, a conclusão atingida carece, pois, de consistência epistêmica, e o diálogo chega ao seu fim, aparentemente, como afirmamos no início, colocando-nos em face de uma dupla negatividade ou aporia: não sabemos o que é a virtude nem se ela pode ser ensinada. Sócrates, porém, deve agora "ir a outra parte". O filósofo exorta, então, Mênon para que este não esmoreça e se esforce por persuadir seu companheiro Ânito daquelas coisas de que ele próprio, Mênon, foi persuadido na discussão, a fim de que Ânito se torne mais doce ou calmo em seu comportamento, o que seria, sem dúvida, prestar um grande serviço aos atenienses. ${ }^{53}$

O diálogo se encerra nesse ponto, deixando-nos a impressão de um aparente fracasso do debate levado a efeito por Sócrates e seus interlocutores. Mas o leitor ou espectador do drama desenvolvido não pode se deter aí: conforme observamos anteriormente, ele deve tentar ir além e, colaborando com Platão, buscar levar adiante a difícil tarefa da interpretação e da compreensão, extraindo a significação dramática derradeira que o filósofo visa produzir por meio da ação que foi desdobrada diante de nossos olhos. Ora, assim fazendo, o leitor ou espectador poderá perceber duas coisas fundamentais: em primeiro lugar, que as palavras finais de Sócrates, apesar de exaltarem, aparentemente,

\footnotetext{
${ }^{51}$ Mênon, 99 e-100 a.

${ }^{52}$ Mênon, 100 a.

${ }^{53}$ Mênon, 100 b-c.
} 
os políticos atenienses como homens divinos e inspirados por um sopro numinoso, não devem ser tomadas literalmente, mas, antes, devem ser lidas como um procedimento discursivo irônico interno ao diálogo e, portanto, como uma formulação discursiva ambivalente, por meio da qual o filósofo promove uma profunda desqualificação do establishment político ateniense diante de seus interlocutores. ${ }^{54}$ De fato, o que Sócrates está dizendo, não sem uma ponta de sarcasmo, é que a virtude dos homens políticos de sua cidade, ao ocorrer sem o concurso do pensamento (áneu noû) e por um acaso divino (theia[i] moíra[i]), é uma virtude cega, irracional e desprovida de cognição, um evento que acontece, pois, à sua revelia e que não é por eles controlado. Com isso, Sócrates efetua uma dura crítica do valor dos políticos de Atenas, ${ }^{55}$ apontando, ao mesmo tempo, para aquela que seria a alternativa a eles: a aparição de um homem dotado de verdadeira areté, porque portador do conhecimento do que é a areté em si mesma e, como tal, capaz de ensiná-la aos seus semelhantes. Em segundo lugar, e adentrando, agora, o terreno da ironia propriamente dramática, que se há um fracasso nas discussões entabuladas no diálogo, esse fracasso se deve não a Sócrates, mas a Mênon, ${ }^{56}$ e que tal é assim justamente porque Mênon descura da filosofia e é desprovido de "paciência dialética", sendo dominado pelo mais intenso páthos do poder. Com efeito, ao longo de todo o diálogo, a atuação de Mênon nos mostra que estamos diante de um homem profundamente ambicioso e pragmático, mais interessado no êxito político e em suas benesses do que na consecução de um genuíno conhecimento acerca da natureza da excelência ou da virtude. Podemos dizer, por isso, que a relação do nobre tessálio com a virtude é uma relação meramente instrumental ou utilitária, sem qualquer tipo de comprometimento mais profundo, e que, no fim das contas, o que ele quer de Sócrates é não uma virtude que dependa do conhecimento e que provoque uma transformação verdadeira da práxis, mas uma virtude que se possa usar como uma ferramenta, a fim de atingir objetivos políticos e mundanos ordinários. Estamos aí,

\footnotetext{
${ }^{54}$ Cf. Gooch (1987, p. 191-193; 202) e Bluck (2010, p. 424-427).

${ }^{55}$ Ver Canto-Sperber (1993, p. 107).

${ }^{56}$ Cf. Koyré (1995, p. 31).
} 
indiscutivelmente, diante da ironia dramática mais profunda e decisiva da obra, cuja significação o leitor do diálogo é chamado a apreender: toda a ação desenvolvida em cena gira em torno de uma discussão sobre a virtude, mas Mênon, interlocutor principal de Sócrates no texto, jamais poderá compreender realmente o verdadeiro significado desse conceito, incapaz que é de se submeter à lenta e paciente pedagogia da dialética socrática. O fiasco da discussão apresentada pelo texto deve ser, assim, relativizado: há um fracasso, sem dúvida, do diálogo, mas tal fracasso resulta das deficiências filosóficas e, por que não dizer?, morais de Mênon. Fosse Mênon menos pragmático e intelectualmente menos afoito, manifestasse ele alguma verdadeira disponibilidade para a filosofia e para o exercício da reflexão e do pensamento, veríamos, então, que a virtude, embora não seja ensinada pelos políticos de Atenas, é passível de um certo ensinamento por parte daquele que realmente a conheça (entenda-se: o filósofo, representado no diálogo por Sócrates) e que os seus germes não nos são, pois, completamente estranhos, encontrando-se localizados no fundo de nosso ser, tal como na alma do escravo se encontravam as sementes do conhecimento geométrico.

\section{Referências}

BLUCK, R. S. Plato's Meno. Cambridge: Cambridge University Press 2010 [1961].

CANTO-SPERBER, M. Ménon. Traduction et présentation. Paris: Flammarion, 1993 [1991].

CROISET, A. Gorgias. Ménon.Texte établit et traduit, avec la colaboration de L. Bodin. Paris: Les Belles Lettres, 1965.

FRIEDLÄNDER, P. Plato: An Introduction. Translated by Hans Meyerhoff. Princenton: Princenton University Press, 1973 [1958].

GRISWOLD, JR., C. Irony in the Platonic Dialogues. Philosophy and Literature, John Hopkins University Press, v. 26, p. 84-106, 2002.

GOOCH, P. Irony and Insight in Plato's Meno. Laval Theologique et Philosophique, Université Laval, v. 43, n. 2, 189-204, 1987. 
GORDON, J. Turning Toward Philosophy. Literary Device and Dramatic Structure in Plato's Dialogues. Pennsylvania: The Pennsylvania State University Press, 1999.

IGLÉSIAS, M. Platão. Mênon. Tradução de Maura Iglésias. Rio de Janeiro: Ed. PUC-Rio; Loyola, 2001.

KLEIN, J. A Commentary on Plato's Meno. Chicago: The University of Chicago Press, 1992 [1965].

KOYRÉ, A. Introduction à la lecture de Platon. Suivi d'entretiens sur Descartes. Paris: Gallimard, 1995 [1962].

STRAUSS, L. La cité et l'homme. Traduction et présentation d'Olivier Sedeyn. Paris: Le Livre de Poche, 2005.

Recebido em 30 de julho de 2017. Aprovado em 25 de setembro de 2017. 